\title{
Improvements of Power Factor and Torque of a Synchronous Reluctance Motor with a Slit Rotor
}

\author{
Masayuki Nashiki Member (Okuma corporation, m_nashiki@ybb.ne.jp) \\ Yoshimitu Inoue Non-member (Okuma corporation, y-inoue@gmx.okuma.co.jp) \\ Youichi Kawai Non-member (Okuma corporation, y-kawai@gmx.okuma.co.jp) \\ Takanori Yokochi Non-member (Okuma corporation, t-yokochi@gmx.okuma.co.jp) \\ Akiyoshi Satake Member (Okuma corporation, a-satake@gmx.okuma.co.jp) \\ Shigeru Okuma Member (Nagoya University, okuma@okuma.nuee.nagoya-u.ac.jp)
}

Keywords: reluctance motors, slit rotor, flux barrier rotor, power factor, efficiency, torque ripple, finite-element methods

Power factor and torque of a synchronous reluctance motor with a slit rotor are studied. Divided teeth made of powder magnetic core and improved windings are adopted to get high density winding and to shorten coil ends. Stainless sheet and soft magnetic metal sheet with adhesive are adopted to strengthen the rotor and the rotor structure is improved to enlarge the saliency ratio $\left(L_{d} / L_{q}\right)$. As the result, the power factor of more than 0.8 and the torque of 1.6 times at same motor size are attained.

SynRM has good features to be made without permanent magnets and to be controlled in constant power control. But SynRM has several problems. One problem is low power factor $0.5 \sim 0.6$. Other problem is big motor size. The length of coil end is large and the winding space factor in slot is not so large.

Many rotor improvements were proposed, but stator improvements were least. In this paper, both stator improvements and rotor

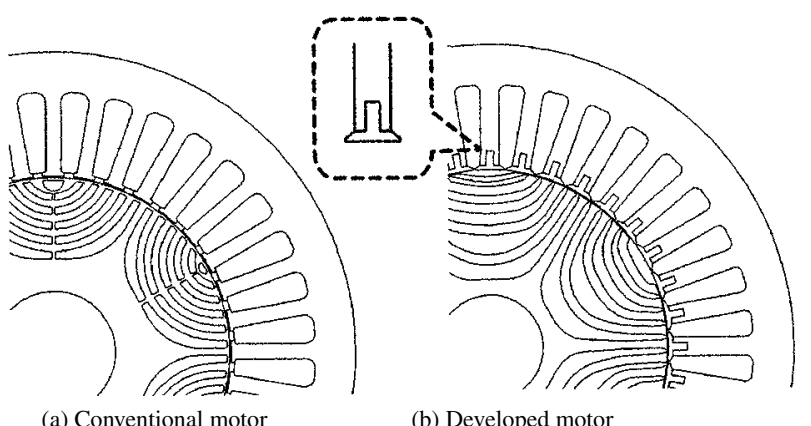

Fig. 1. Cross section view of the SynRM

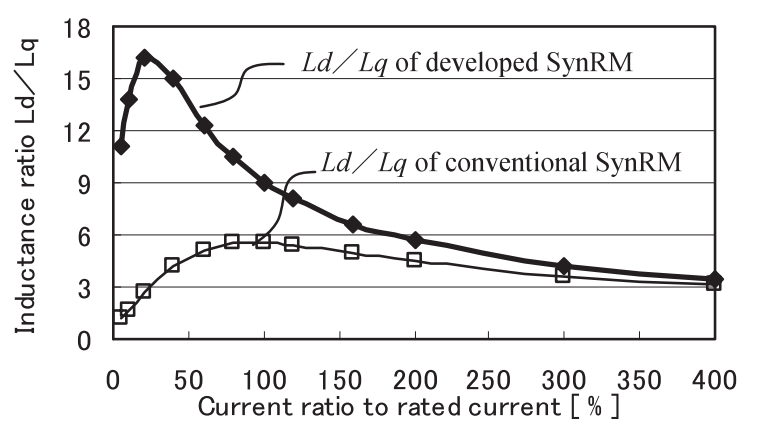

Fig. 2. Inductance ratio $L d / L q(\mathrm{FEM})$ improvements mentioned above are proposed.

Fig. 1 shows Cross section view of the SynRM. Partial expanded figure shows divided teeth.

Fig. 2 shows saliency ratio $L_{d} / L_{q}$. The $L_{d} / L_{q}$ of developed SynRM is 1.6 times compared with that of conventional SynRM at rated torque and 2.4 times at $60 \%$ rated torque.

Fig. 3 shows torque characteristics. The torque of developed SynRM is increased by $64 \%$ at rated torque.

Fig. 4 shows power factor. That of developed SynRM is $78 \%$ at rated torque and approximately over than $80 \%$ at small torque area.

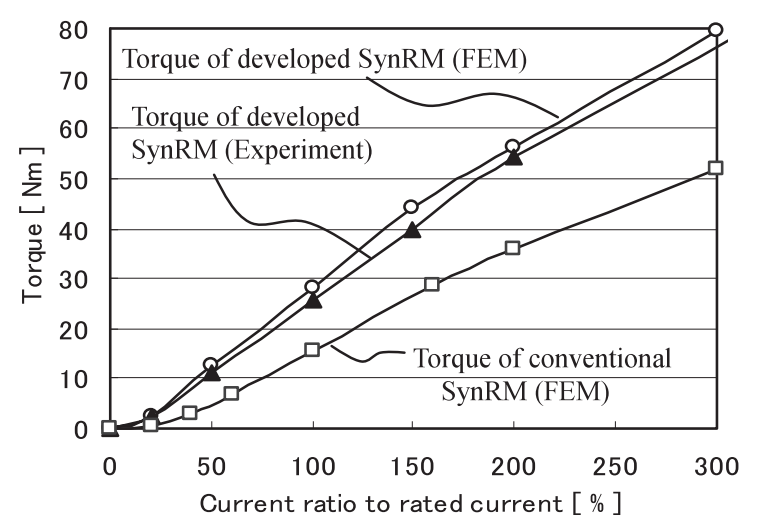

Fig. 3. Torque $T$ versus Current

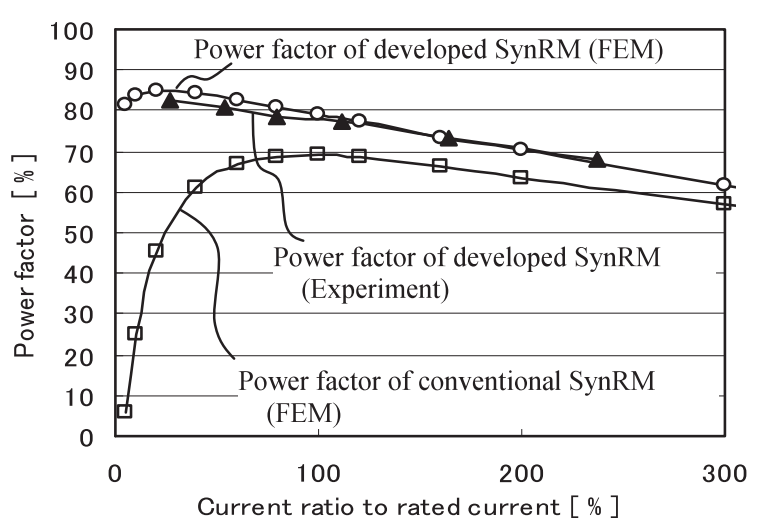

Fig. 4. Power factor $\alpha$ versus Current 


\title{
スリット回転子を用いたシンクロナスリラクタンスモータの 力率・トルク向上に関する検討
}

$\begin{array}{cccc}\text { 正 員 梨木 } & \text { 政行* } & \text { 非会員 井上 芳光* } \\ \text { 非会員 川井 庸市* } & \text { 非会員 横地 孝典* } \\ \text { 正 員 佐竹 明喜* } & \text { 正 員 大熊 } & \text { 繁** }\end{array}$

\section{Improvements of Power Factor and Torque of a Synchronous Reluctance Motor with a Slit Rotor}

Masayuki Nashiki*, Member, Yoshimitu Inoue*, Non-member, Youichi Kawai*, Non-member,

Takanori Yokochi*, Non-member, Akiyoshi Satake*, Member, Shigeru Okuma**, Member

\begin{abstract}
Power factor and torque of synchronous reluctance motors with a slit rotor are studied. In there stators, divided teeth made of powder magnetic core are adopted and windings are improved to get high space factor of stator windings and to shorten coil ends. In there rotors, stainless sheets are inserted among soft magnetic metal sheets with adhesive to strengthen the rotors and rotor structure is improved to enlarge the saliency ratio $\left(L_{d} / L_{q}\right)$. As the result, the power factor 0.78 and 1.6 times torque at same motor size are attained.
\end{abstract}

キーワード：リラクタンスモータ, スリット回転子, フラックスバリア形ロータ, 力率, 効率, トルクリップル, 圧粉磁心

Keywords: Reluctance motor, Slit rotor, Flux barrier rotor, Power factor, Efficiency, Torque ripple, powder magnetic core

\section{1. まえがき}

スリット回転子を持つフラックスバリア型のシンクロナ スリラクタンスモータ (1) (9) $($ SynRM) は，永久磁石を使用 することなく製作できるので低コストであり，界磁弱め制 御による定出力制御が可能であるという特徵を持っている。 トルクリップルについても，回転子構造を改良することに より低減 (2)(3)(8) が進められてきた。

しかし，固定子に関しては改良 ${ }^{(4)}$ が十分ではなく，固定 子巻線が分布巻き構造であることから, スロット内の巻線 占積率が $50 \%$ 程度と低く, コイルエンド長も長くなってい る。また, 回転子については多くの研究 ${ }^{(1) \sim(9)}$ がなされてき たが，回転子の特性より力率も $0.5 \sim 0.6$ と低く, 改善の余 地が残っている。なお, 永久磁石を SynRM へ補助的に活 用して力率, 効率を改良する技術 ${ }^{(10)(11)}$ も一つの方向として 研究されているが，本研究の対象としていない。

前記のように, SynRM は電動機サイズ, 力率, 効率など

\footnotetext{
*オークマ (株) 研究開発部

T 480-0193 愛知県丹羽郡大口町下小口 5-25-1

Okuma Co., Ltd

5-25-1, Simooguchi, Oguti-cho Niwa-gun, Aichi 480-0193

** 名古屋大学

于 464-8603 名古屋市千種区不老町

Nagoya University

Furo-cho, Chikusa-ku, Nagoya 464-8603
}

の問題があり，実用化があまり進んでいない。

本研究では, SynRM の固定子および回転子の改善方法 について検討し，力率およびトルクを総合的に改善する。

固定子の改良については，(a）固定子コアの歯の先端部 を分割して圧粉磁心で製作し, 巻線巻回の難易度を改善す ることにより巻線占積率の改善，（b）コイルエンドの縮小 を行う。

回転子の改良については，(c) ステンレス板を電磁鋼板 に部分的に挿入して回転子を補強することにより回転子外 周および回転子内部の補強用接続部を排除し, $\mathrm{q}$ 軸インダ クタンス $L_{q}$ を低減して力率を改善している。

その他, 良く知られ, 最も効果的なトルク改善策である (d) エアギャップ短縮は $0.3 \mathrm{~mm}$ から $0.13 \mathrm{~mm}$ に短縮した。 これら (a)，(b)，(c)，(d) の対応を行った改良型 SynRM について非線形有限要素法 (FEM) によるシミュレーショ ンと試作を行い, 力率 78\%と従来型 SynRM の 1.6 倍の連 続トルクを実現することができた。

以下，第 2 章では従来型 SynRM の問題点を示し，第 3 章では改良型 SynRM とそのシミュレーション結果につい て示す。第 4 章では試作結果について示し, 第 5 章はまと めである。

\section{2. 従来型 SynRM の問題点}

SynRM は永久磁石を使用することなく製作できるので 


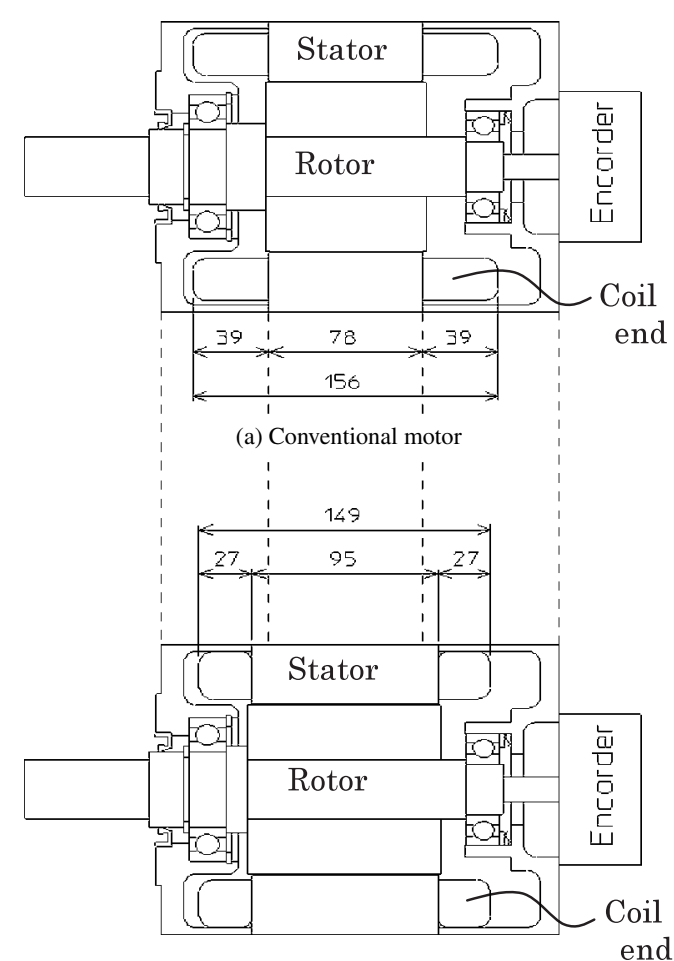

(b) Developed motor

困 1 SynRM の縦断面困

Fig. 1. Vertical section view of the SynRM.

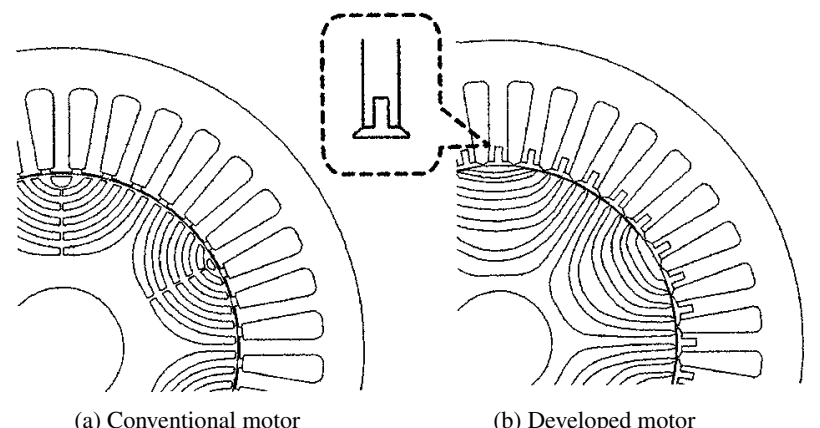

図 2 SynRM の横断面図

Fig. 2. Cross section view of the SynRM.

表 1 SynRM のパラメータ

Table 1. SynRM parameters.

\begin{tabular}{|l|c|c|}
\hline \multicolumn{1}{|c|}{ Parameters } & $\begin{array}{c}\text { Conventional } \\
\text { motor }\end{array}$ & $\begin{array}{c}\text { Developeded } \\
\text { motor }\end{array}$ \\
\hline Phase, Pole & 3 Phase, 6 pole & 3 Phase, 6 pole \\
\hline Slot number & 36 slots & 36 slots \\
\hline Stator outer dia. & $\phi 172 \mathrm{~mm}$ & $\phi 172 \mathrm{~mm}$ \\
\hline Partial teeth & no & 36 pieces \\
\hline Air gap & $0.3 \mathrm{~mm}$ & $0.13 \mathrm{~mm}$ \\
\hline Rotor outer dia. & $\phi 100 \mathrm{~mm}$ & $\phi 100 \mathrm{~mm}$ \\
\hline Outer bridge & $0.5 \mathrm{~mm}$ & $0 \mathrm{~mm}$ \\
\hline Inner bridge & $0.5 \sim 1 \mathrm{~mm}$ & $0 \mathrm{~mm}$ \\
\hline Core length & $78 \mathrm{~mm}$ & $95 \mathrm{~mm}$ \\
\hline Rated torque & $15.7 \mathrm{Nm}$ & $25.7 \mathrm{Nm}$ \\
\hline Rated current $i_{d}$ & $19.5 \mathrm{~A}$ & $16 \mathrm{~A}$ \\
\hline Rated current $i_{q}$ & $38.2 \mathrm{~A}$ & $36 \mathrm{~A}$ \\
\hline
\end{tabular}

電学論 D, 126 巻 2 号, 2006 年
低コストで，界磁弱め制御が可能であるという特徵を持っ ているが，以下に示すような問題がある。

$\langle 2 \cdot 1\rangle$ 従来型SynRM の構成図 1(a)にスリット回 転子を用いた従来型 SynRM の縦断面図を示し, 図 2(a)に 横断面図を示す。回転子鉄心の構造は, 図 2 に示すように, 回転子の磁極間に配置された細磁路と称する細い磁路とス リットが交互に配置された構造となっている。表 1 に本論 文で使用する従来型 SynRM と改良型 SynRM のパラメー 夕および主要特性を示す。なお, 本論文の主旨ではないが, スリット等に起因するトルクリップル低減のため, 回転子 の各磁極の回転方向位置は，60 度等分配置ではなく，相対 的に回転方向にわずかにシフトしている。参考文献 (2), (3) にその詳細が記述されている。

$\langle\mathbf{2} \cdot \mathbf{2}\rangle$ 力 率 従来型 SynRM の問題点の一つは, 力率が 0.6 程度と小さいことである。力率とモータパラメー 夕との関係については第 3 章で詳述するが, 低力率の原因 は, $\mathrm{d}$ 軸インダクタンス $L_{d}$ がエアギャップ部の磁気抵抗が 大きいこと等により十分に大きくできていないこと, $\mathrm{q}$ 軸 インダクタンス $L_{q}$ が $\mathrm{q}$ 軸方向の漏れ磁束等により十分に 小さくできていないことが原因である。

$\langle\mathbf{2} \cdot \mathbf{3}\rangle$ 効 率 SynRMのもう一つの問題は, 効率 が永久磁石を活用したモー夕に比較して低いことである。 その原因は, 前記の低力率，巻線占積率が低いため巻線抵 抗が大きいこと，コイルエンドが長いことである。電動機 の 3 相分布巻きの構造上, 全節分布巻巻線のスロット内の 占積率（絶縁皮膜を含む導体断面積／スロット断面積）が $50 \%$ 程度と小さく, かつ, コイルエンド部で 3 相巻線が交差 する構造となり, 複雑であるため軸方向長さが大きくなっ ている。一方, いわゆる集中巻巻線を備える表面磁石シン クロナスモータ (SPMSM), 埋込磁石シンクロナスモータ (IPMSM）は巻線占積率が大きく，コイルエンドが短いと いう特徴がある。したがって, SynRMの巻線は, 同一電圧 の条件で集中巻きの電動機の巻線に比較すると, 巻線が細 く，長くなるため，巻線抵抗が大きくなっている。

〈2・4〉 電動機の大きさとコスト 他の問題点として, 電動機の大きさがあり, 前記のコイルエンドが長いこと, そして, 前記の力率, 効率の問題が大きさに起因している。 また，高価な永久磁石は使用しないが，電動機の大きさが コストに影響している。また，分布巻は各相の巻線が入り 組んだ構成となり，その製作性が劣るという問題もある。

\section{3. 改良型 SynRM}

前記の諸問題を改善する試みである改良型 SynRM の縦 断面図を図 1(b) に, 横断面図を図 2(b) に示す。なお, 本研 究 SynRM は, 工作機械サーボ用途における重切削加工時 の高トルク要求に応えるため, 連続定格トルクの向上, 効 率向上を目的としている。重切削時のモー夕回転数は通常 $1000 \mathrm{~min}^{-1}$ 以下で, 最大回転数は $2000 \mathrm{~min}^{-1}$ 程度である。

$\langle\mathbf{3 \cdot 1 \rangle}$ 固 定子 巻線の占積率向上, コイルエンドの 縮小を目的として歯の先端部コアを分割する構造とした。 


\section{（1）歯の先端部の分割コア化}

固定子の改善として, 図 2(b) の SynRM 横断面図㧍よび その部分拡大図に示すように，歯の先端部を分割コアとし た。この分割コアを部分歯と称して㧍り，圧粉磁心で製作 した。歯の先端を部分歯とする主目的は, 巻線の巻回を容 易化することによる巻線占積率の向上と, コイルエンド長 の縮小である。他の効果として, スロットの開口部を縮小 することにより固定子と回転子間の対向面積を増加させ, エアギャップ部の磁気抵抗を低減し， d 軸インダクタンス $L_{d}$ を増加させる効果がある。また，スロットの開口部を小 さくできるので, 開口部に起因したトルクリップルを低減 する効果もある。

この部分歯は，量産時には，金型による精密プレス成形 で低コストに製作でき，小さい形状なので比較的高精度に 製作が可能である。なお，部分歯の形状は，部分歯を固定 子コアに固定できること，部分歯をプレス成型で製作でき ること, 部分歯と固定子コアとの対向面積を広めに得られ ることを条件に図 2(b) の形状とした。

なお，圧粉磁心 (PMC) の磁気特性は図 4 に示すよう に比透磁率が 500 程度と低いので, 部分歯の径方向厚みを $1.2 \mathrm{~mm}$ と薄くしている。

（2）巻線の占積率向上, コイルエンドの短縮

前記の巻線占積率，コイルエンド長，巻線の製作性の問 題の主要原因の一つは，スロットの開口部が狭いことであ り，開口部を広くすることにより改善が可能である。

部分歯を採用した固定子の組み立て順は, 固定子コアに 部分歯を装着する前に巻線を巻回し，その後に部分歯を装 着し固定する。したがって, スロット開口部が広い状態で, 巻線束をほぼ整列された状態で扱入することができるので 巻線占積率を高くできる。同時に，スロット開口部が狭い 場合に巻線作業の都合上必要としたコイル長を短縮でき, コイルエンド部の軸方向長さを短縮することができる。

具体的には, コイルエンド長は従来の $38 \mathrm{~mm}$ から $27 \mathrm{~mm}$ 以下に $11 \mathrm{~mm}$, 率で $29 \%$ 短縮した。この結果を反映し、コ イルエンドの短縮が両側で $22 \mathrm{~mm}$ となるので, 試作電動機 のコア積厚を従来の $78 \mathrm{~mm}$ から $17 \mathrm{~mm}$ 増加させ, $95 \mathrm{~mm}$ のコア積厚の電動機とした。従来型 SynRM とは同一の外 形形状として性能比較することとし, 図 3 に示すようにト ルクを 1.22 倍とし， 22\%増加できることになる。

また，巻線占積率を従来の $49 \%$ から $61 \%$ に向上した。こ の効果による同一銅損の条件での理論計算では, 電流, 卜 ルクを $12 \%$ 増加できることになる。しかし, 前記のコア積 厚の増加により銅損が増加する効果もあり, 試作電動機に おいて温度上昇試験を行った結果, 表 1, 図 3 に示すよう に, 許容電流は 0.919 倍となり, $8.1 \%$ 減少した

$\langle\mathbf{3} \cdot \mathbf{2}\rangle$ 回 転子回転子内部の $\mathrm{q}$ 軸方向磁束を低減 するため回転子補強用のステンレス円板を電磁鋼板の間に 挿入した。

\section{（1）ステンレス板を使用した回転子構造}

回転子は接着剤が両面に塗布された珪素鋼板を使用し，

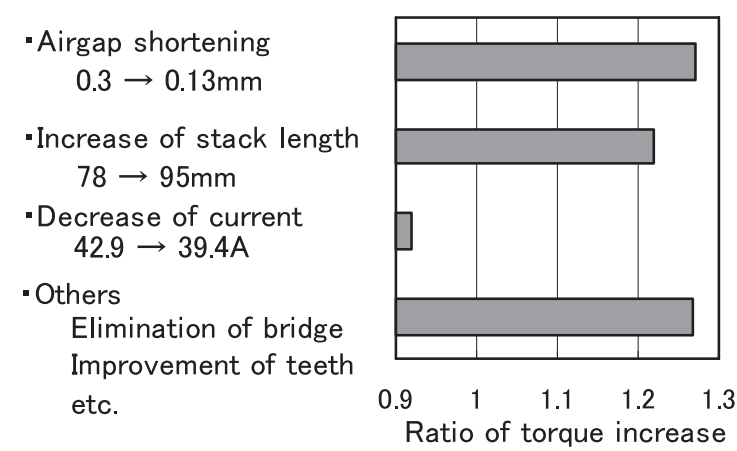

図 3 従来モー夕に対するトルク増加率

Fig. 3. Ratio of torque increase to conventional motor.

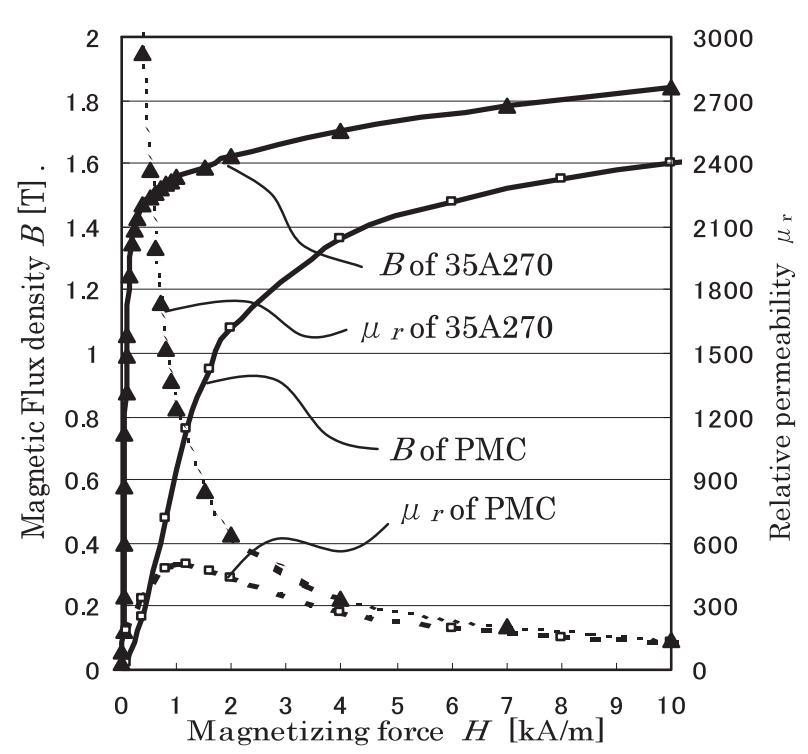

図 4 珪素鋼板 35A270 と圧粉磁心 PMC の磁気特性

Fig. 4. Magnetic characteristics of silicon steel board 35A270 and powder magnetic core PMC.

積層珪素鋼板の 20 枚ごとに補強用の非磁性ステンレス円板 を挿入する構造とした。回転子のスリットで分離された各 細磁路は，それぞれがステンレス円板に接着固定された構 造となっている。特に, 最も内径側の珪素鋼板とステンレ ス円板とは広い面積で強固に接着固定され，それらはほぼ 一体となって回転子軸へも接着剤で強固に固定されている。 このような回転子構造により, 図 2(a) の従来型 SynRM の回転子構造を支える回転子外周の接続部, 回転子内部の 各磁路間の接続部を排除した。その結果, 後に詳述するが, $\mathrm{q}$ 軸方向インダクタンス $L_{q}$ を小さくすることができる。

また, 図 2(b) の改良型 SynRM から判るように, 回転子 内部のスペースを利用して回転子内部の各スリット幅を拡 大し，q 軸方向磁束を低減している。同時に，回転子内部 の各スリットに挟まれた細磁路の形状についても磁気抵抗 を低減する工夫を行っており, 回転子の外周近傍の細磁路 の幅 Wout に対して, 回転子の内部側の細磁路の幅 Win を 10〜20\%拡大している。

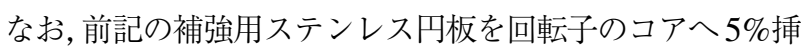


入するので，単純に考えると 5\%のトルク低減が予測される が, 3 次元シミュレーションの結果, 約 $2 \%$ のルク低減で あった。トルク低減が小さい理由は, 回転子の磁束が 3 次元 的に軸方向へも存在するので磁束の回り込みがあるためと 考えられる。強度的には, 接着剤の接着強度は $520 \mathrm{~N} / \mathrm{cm}^{2}$, $T=100^{\circ} \mathrm{C}$ で, $6000 \mathrm{~min}^{-1}$ の時, 安全率 10 である。ステ ンレス板 SUS316 にかかる最大応力は $35 \mathrm{~N} / \mathrm{mm}^{2}$ であり, その疲労強度 $102 \mathrm{~N} / \mathrm{mm}^{2}$ より安全率は 2.93 である。この 結果から，ステンレス板を使用した回転子補強は，トルク 低減が小さく，有効な回転子補強方法と考える。

\section{（2）改良型SynRM の磁気特性}

良く知られているように, SynRM の発生トルク $T$ は次 式で表される。

$$
\begin{aligned}
T & =P_{n}\left(L_{d}-L_{q}\right) i_{q} i_{d} \ldots \ldots \ldots \ldots \ldots \ldots \ldots \ldots \ldots \ldots \ldots \ldots \ldots \ldots \ldots \ldots \ldots \ldots \ldots
\end{aligned}
$$

ここで, $P_{n}$ は極対数, $\phi_{d}, \phi_{q}$ は $\mathrm{d}, \mathrm{q}$ 軸の磁束鎖交数であ る。なお, 本研究電動機で使用した板厚 $0.35 \mathrm{~mm}$ の珪素鋼 板 35A270 の磁気特性は図 4 に示すように非線形であり, $L_{d}, L_{q}$ を一定值として扱うことは難しい。

また，SynRMのベクトル図は図 5 のように表され，力 率 $P_{f}$ は電圧 $V_{a}$ と電流 $i_{a}$ の位相差の余弦であり, 巻線抵抗 $R_{a}$ を無視すると次式で表される。

$$
P_{f}=\cos \left(\theta \mathrm{m}+\left(90^{\circ}-\theta c\right)\right)
$$

ここで, $\theta \mathrm{m}$ は d 軸と磁束鎖交数 $\phi_{a}$ との位相差であり，ま た, $\mathrm{q}$ 軸と電圧 $V_{a}$ との位相差でもある。具体的に力率 $P_{f}$ を 0.8 以上とするためには， $\left(\theta \mathrm{m}+\left(90^{\circ}-\theta c\right)\right) \leqq 36.87^{\circ}$ と しなければならない。ここで，理想的に $L_{q}=0$ であって， $\theta \mathrm{m}=0$ であったとしても, 力率 $P_{f}$ を 0.8 以上とすること が可能な電流位相角は，(3) 式より $\theta \mathrm{c} \leqq 53.13^{\circ}$ となる。

一方, 本研究電動機で使用した珪素鋼板 35A270 の磁気 特性は図 4 に示す特性で，特殊な特性ではなく一般的な特 性をしているが，相当に非線形である。比透磁率 $\mu_{r}$ の具 体值の例としては，1.3 T 以下の時 5000 以上, $1.5 \mathrm{~T}$ で約 2000，1.6 T 以上では 1000 以下の值となる。1.5 T 以上で は急激に比透磁率 $\mu_{r}$ が小さくなる。なお，図 4 の磁気特性 は，通常両対数グラフで示すことが多いが，磁気飽和の程 度を見易いように方眼紙上に描写している。

時として, 線形な磁気特性を前提にSynRM の電流位相 角 $\theta \mathrm{c}$ を $45^{\circ}$ で論じることがあるが, 図 4 の磁気特性から 明らかなように, 磁束密度が $1.5 \mathrm{~T}$ 以上となるような電動機 サイズでは最大トルクが得られる電流位相角 $\theta \mathrm{c}$ は $45^{\circ} よ$ り大きく, 磁束密度の設定が SynRM の特性上重要である。

本研究電動機外形は直径 $172 \mathrm{~mm}$ で，工作機械等の産業 機械で多く使用される電動機サイズであり，この程度のサ イズの SynRM では十分な大きさの磁界の強さ $H$ を得るこ とができ, 磁束密度 $B$ が $1.5 \mathrm{~T}$ よりきな非線形な領域を 使用することになる。本研究では，詳細を後に示すが，定 格トルクでの電流位相角 $\theta \mathrm{c}$ を $66^{\circ}$ に設定した。

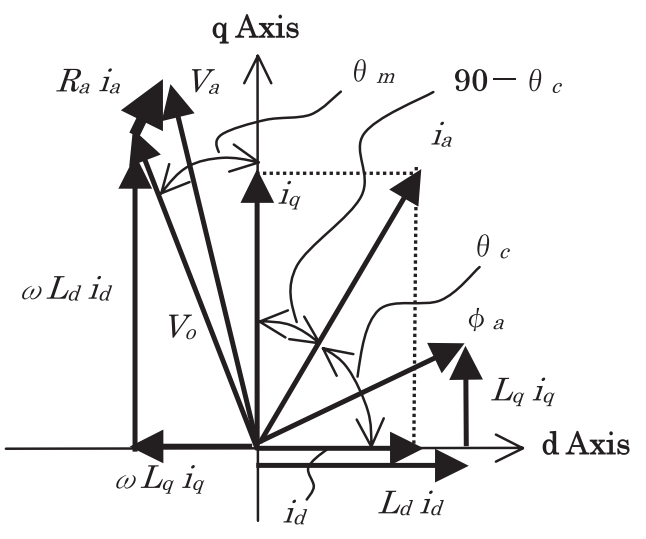

困 5 SynRM のベクトル図

Fig. 5. Vector diagram of SynRM.

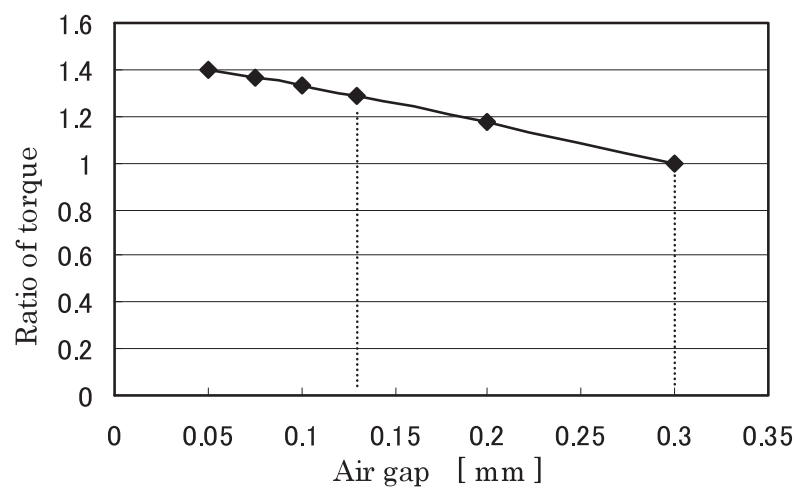

図 6 トルクのエアギャップ依存性

Fig. 6. Relationship between air gap and ratio of torque.

〈3・3〉 固定子と回転子の間のエアギャップ部＼cjkstart固定 子と回転子の間のエアギャップ長と出力トルクとの関係を 非線形有限要素法 FEM で評価した結果, 図 6 の特性となっ た。SynRMのエアギャップ長は, 通常 $0.3 \mathrm{~mm}$ 程度に設定 されることが多いが, 本電動機では $\mathrm{d}$ 軸インダクタンス $L_{d}$ を大きくしトルクを増加させるため, $0.13 \mathrm{~mm}$ に縮小した。

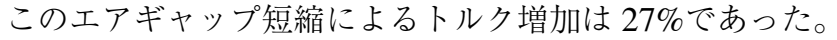

また，〈3・1〉節で説明したように，部分歯の採用により スロットの開口部を縮小し, 固定子と回転子間の対向面積 を増加させ，エアギャップ部の磁気抵抗を低減させること により $\mathrm{d}$ 軸インダクタンス $L_{d}$ を増加させた。

$\langle\mathbf{3} \cdot \mathbf{4}\rangle$ 磁気特性 $\langle 3 \cdot 1\rangle \sim\langle 3 \cdot 3\rangle$ の改良により $L_{d}, L_{q}$, $L_{d} / L_{q}$ を改善した。

\section{（1） d 軸インダクタンス $L_{d}$ の増加}

図 7 に改良型 SynRM の d 軸インダクタンス $L_{d}$ の非線形 有限要素法によるシミュレーション結果を示す。なお, 水平 軸は連続定格電流に対する\%值で示している。改良前の従来 型 SynRM の特性に比較し, 定格の $50 \%$ では $30 \mathrm{mH} / 11 \mathrm{mH}$ $\fallingdotseq 2.7$ 倍の值となり, 定格では $16 \mathrm{mH} / 9 \mathrm{mH} \fallingdotseq 1.8$ 倍の $L_{d}$ となり，全域で大幅に改善している。特に定格の $100 \%$ 以 下の電流領域での改善が顕著である。

なお，インダクタンス $L_{d}, L_{q}$ は, 非線形有限要素法で磁 


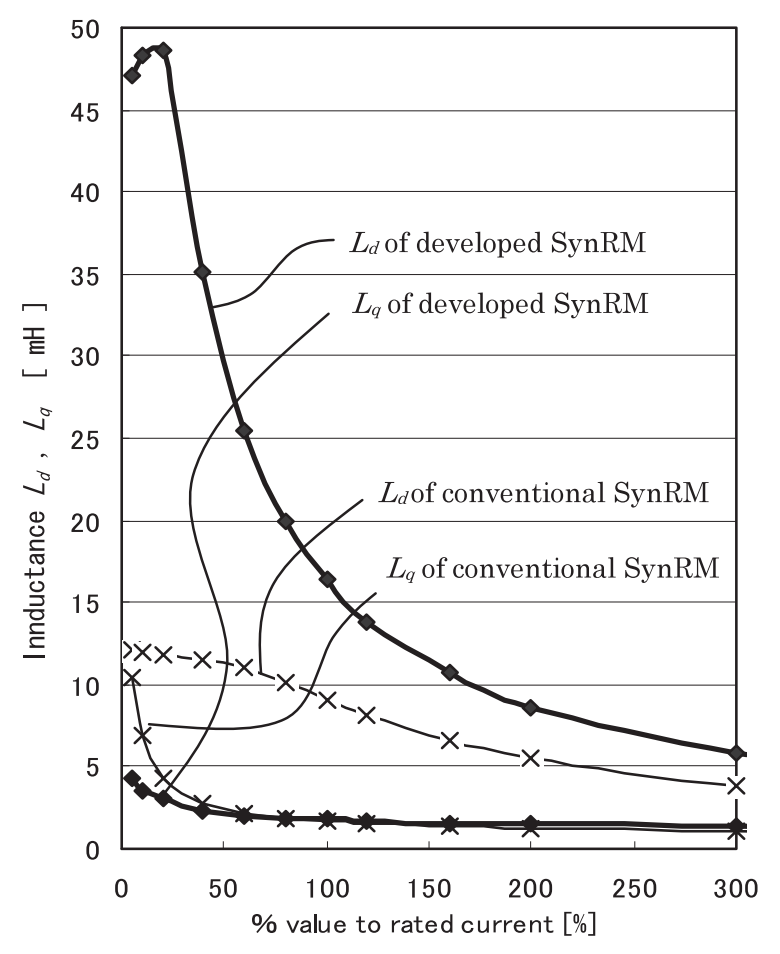

図 7 インダクタンス $L_{d}, L_{q}(\mathrm{FEM})$

Fig. 7. Inductance $L_{d}, L_{q}$ (FEM).

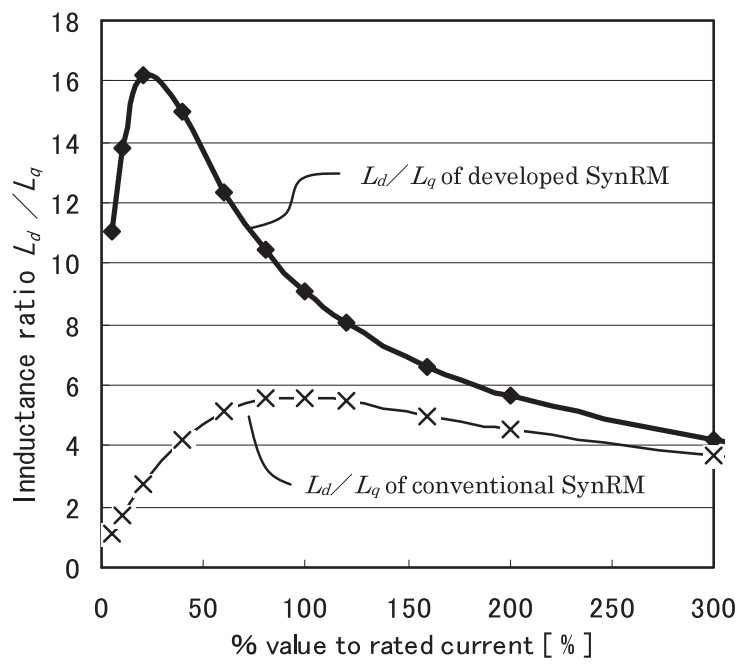

図 8 インダクタンス比 $L_{d} / L_{q}(\mathrm{FEM})$

Fig. 8. Inductance ratio $L_{d} / L_{q}$ (FEM).

束鎖交数 $\phi_{d}, \phi_{q}$ を求め, (1) 式, 2 式の関係から計算する ことができる。

\section{（2） q 軸インダクタンス $L_{q}$ の低減}

図 7 に 軸インダクタンス $L_{q}$ のシミュレーション結果 を示す。従来型 SynRM は電流が定格の 50\%以下の領域で 前記各接続部の漏れ磁束成分が認められ， $L_{q}$ が大きくなっ ている。定格の $50 \%$ 以上の電流領域では両電動機の $L_{q}$ に 大差は無い。

（3）インダクタンス比 $L_{d} / L_{q}$ の改善

図 8 にインダクタンス比 $L_{d} / L_{q}$ の特性を示す。改良型

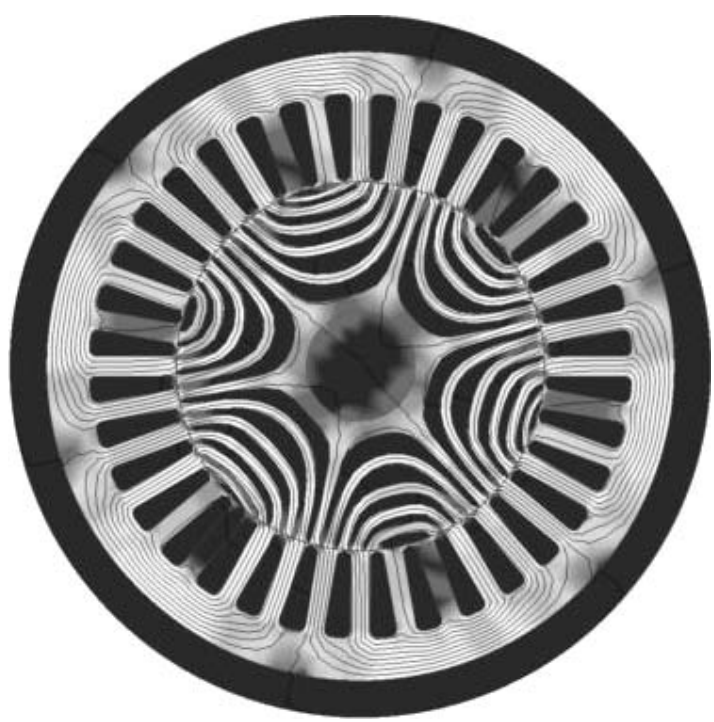

図 9 定格状態での磁束分布例

Fig. 9. Flux distribution of the developed SynRM.

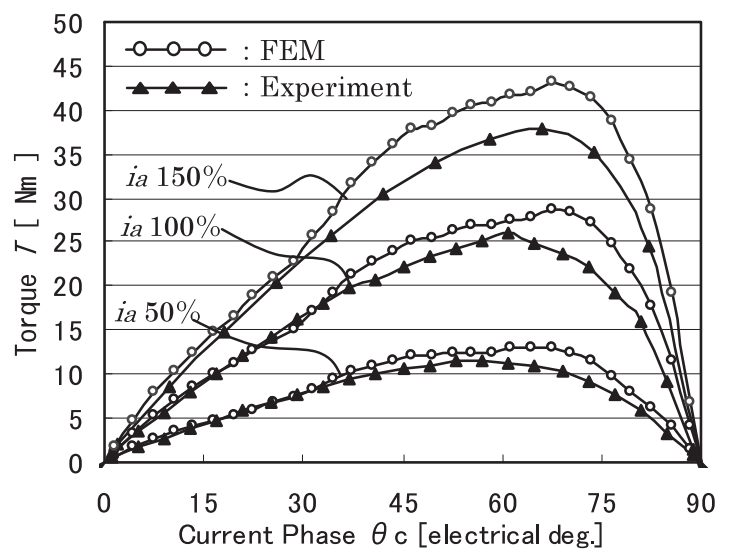

図 10 改良型 SynRM の電流位相角 $\theta \mathrm{c}$-トルク $T$ 特性

Fig. 10. Torque $T$ versus Current phase $\theta \mathrm{c}$.

SynRM の $L_{d} / L_{q}$ は定格電流で 9 , 定格電流の $80 \%$ 以下の 領域では 10 以上の $L_{d} / L_{q}$ となっている。従来型 $S y n R M$ の $L_{d} / L_{q}$ と比較すると, 定格で 1.6 倍, 定格の $50 \%$ では 3 倍と なっている。インダクタンス比 $L_{d} / L_{q}$ で比較して大幅に改 善しており, 効率, 力率, 定出力特性の改善が期待できる。

図 9 に示す改良型 SynRM の定格状態, $\theta \mathrm{c}=66^{\circ}$ での磁 束密度の分布であり, 磁束が回転子磁極中央をほぼ中心と して分布しており，良好な磁束分布となっている。

$\langle\mathbf{3 . 5}\rangle$ トルク $\boldsymbol{T}$ トルク $T$, 力率 $P_{f}$ の改善を前記 $\langle 3 \cdot 1\rangle \sim\langle 3 \cdot 3\rangle$ 節の対策により実現している。改良型 SynRM の電流位相角 $\theta \mathrm{c}$-トルク $T$ 特性のシミュレーション結果を 図 10 に示す。電流位相角 $\theta \mathrm{c}$ が 66 度近傍で最大トルクが 得られることが分かる。なお, 電流 $i_{a}$ は, $\mathrm{d}$ 軸電流 $i_{d}$ と $\mathrm{q}$ 軸電流 $i_{q}$ の合成電流であり, 連続定格電流に対する比較值 で示している。

トルクのシミュレーション結果は図 11 となり, 定格の $300 \%$ でほぼ直線的な特性を得た。従来型 SynRM のシ 
ミュレーション結果と比較して，定格で $80.6 \%$ のトク増 加となった。

図 12 にトルクリップル特性のシミュレーション結果を 示す。トルクリップルは定格トルク比で $5.3 \%$ p_p となり， 実用的に十分使用可能な特性であるが，改善の余地もある。

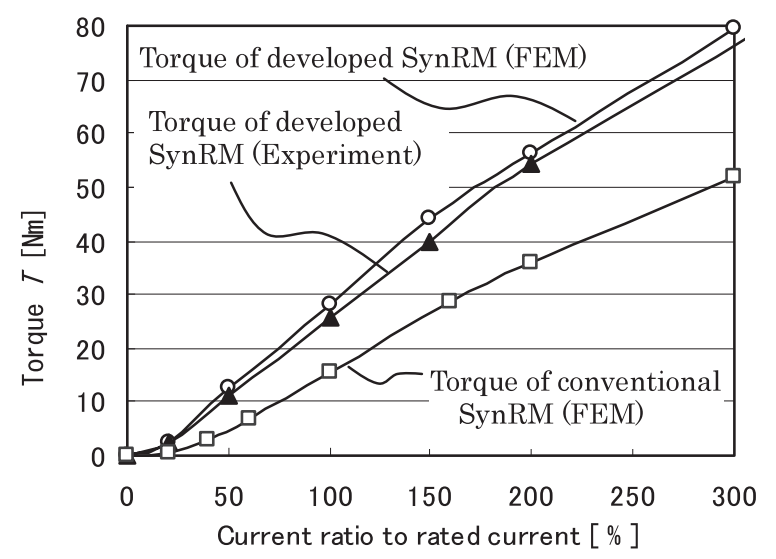

図 11 トルク $T$-電流特性

Fig. 11. Torque $T$ versus Current.

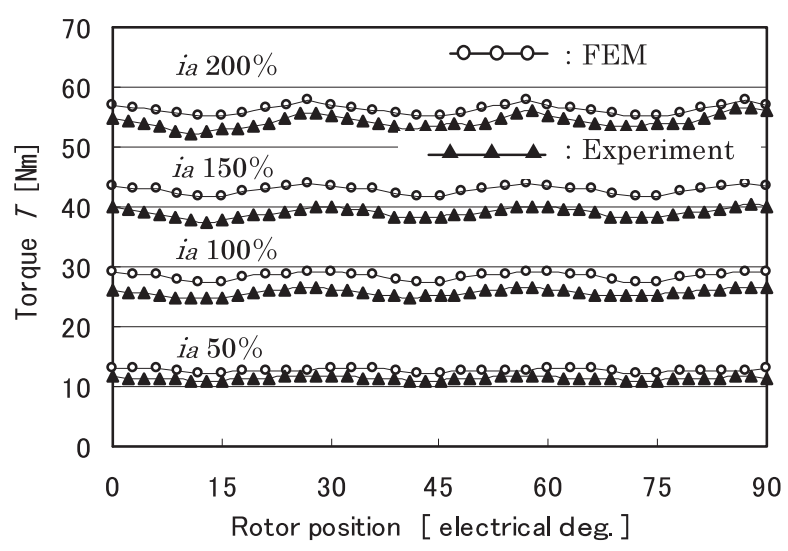

図 12 改良型 SynRM の回転位置 $\theta \mathrm{r}$-トルク $T$ 特性

Fig. 12. Torque $T$ versus Rotor angle $\theta \mathrm{r}$.

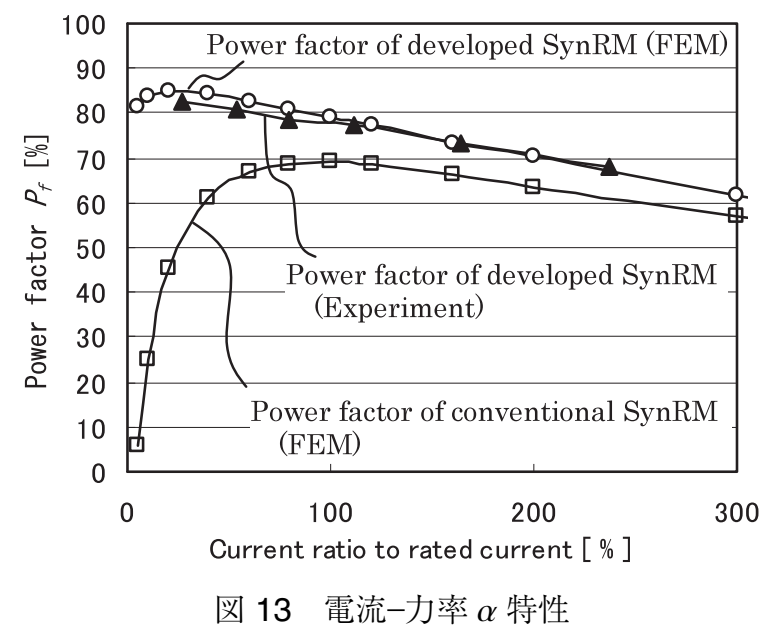

Fig. 13. Power factor $\alpha$ versus Current.
なお，本研究の目的は，トルク増加，力率改善を主とい るので, 改良型 SynRM ではトルクリップルの低減策であ る固定子，回転子のスキューを行っていない。

$\langle\mathbf{3} \cdot \mathbf{6}\rangle$ 力 率 $\boldsymbol{P}_{\boldsymbol{f}}$ 力率 $P_{f}$ のシミュレーション結果は 図 13 となり, 定格以下の大半の領域で力率 $80 \%$ を達成し, 定格で力率 $79 \%$, 定格以上の領域では力率が徐々に低下し ている。

なお力率 $P_{f}$ のシミュレーション方法は, FEM 解析ツー ルとして Infolytica 社の Magnet を使用し非線形磁界解析 を行い, 各巻線の鎖交磁束 $\Phi n$ を求め, 各スロットの巻き 回数を乗じて加算し, 図 5 に示す磁束鎖交数 $\phi \mathrm{a}$ および $\phi \mathrm{a}$ と d 軸との位相差 $\theta \mathrm{m}$ 求め, (3) 式により計算している。こ れは視点を変えると, 眓 5 の電圧 $V_{a}$ と電流 $i_{a}$ の位相差の 余弦を求めているとも言える。

\section{4. 改良型 SynRM の試作}

改良型 SynRM を試作，評価した。困 15 に試作電動機の 固定子, 回転子の概観を示す。なお, 試作電動機のケース 外形形状は, 比較のため, 従来型 SynRM と同一とした。

〈4・1〉 トルク $\boldsymbol{T}$ とトルクリップル＼cjkstart試作電動機の電 流位相角 $\theta \mathrm{c}$-トルク $T$ 特性の測定結果を図 10 に示す。

トルクの電流值に関する線形性は, 図 11 の電流ートルク 特性に示すように $300 \%$ まで良好な特性を確認した。トル クの大きさは, 従来の SynRM に比較して, 定格で $63.7 \%$ の 増加であり，大幅なトルク増加を確認することができた。

出力は, $1000 \mathrm{~min}^{-1}$ で $2690 \mathrm{~W}$ となった。

トルクリップルは, 図 12 の結果となり, その特性形状 はほぼシミュレーション結果と良く合っている。リップル 周期は電気角で 30 度であり，スロットの周期に一致する。 今後の改良課題の一つである。なお, 固定子, 回転子のス キューは行っていない。

ここで，トルク測定值がシミュレーション值に比較して 約 $10 \%$ 程度低い值となっており, その誤差原因として, 電 動機各部の形状誤差, 電磁鋼板の占積率, シミュレーション と試作における磁気特性の差等が考えられる。なお, 従来 型 SynRM と改良型 SynRM のシミュレーション環境, 試 作条件，測定環境は共通であり，相対評価は確度が高い。

$\langle\mathbf{4} \cdot \mathbf{2}\rangle$ 力 率 $\boldsymbol{P}_{\boldsymbol{f}}$ 試作電動機の $1000 \mathrm{~min}^{-1}$ における 力率測定結果を図 13 に示す。シミュレーション結果とほぼ 一致している。定格で力率 78\%であり, 電流が定格 100\%以 下の領域では力率 $80 \%$ を達成している領域もある。

なお位相差の計測は, 電動機駆動装置の $5 \mathrm{kHz}$ PWM イン バー夕が発生する多くの高調波成分を除去するため, 絶縁増 幅器を通した電流信号, 電圧信号の両方を時定数 $0.47 \mathrm{msec}$ の RCフィルターを通して得，両信号の基本波成分の相対 位相を計測した。

$\langle\mathbf{4} \cdot \mathbf{3}\rangle$ 効 率 $\boldsymbol{\eta} \quad$ 試作電動機の $N=1000 \mathrm{~min}^{-1}$ にお ける効率 $\eta$ の評価結果を図 14 に示す。定格電流での効率は 94\%であった。電流が定格の 20\%から 100\%の領域では, 効率 94〜96\%であり, 良好な特性を確認した。特に, 定格 


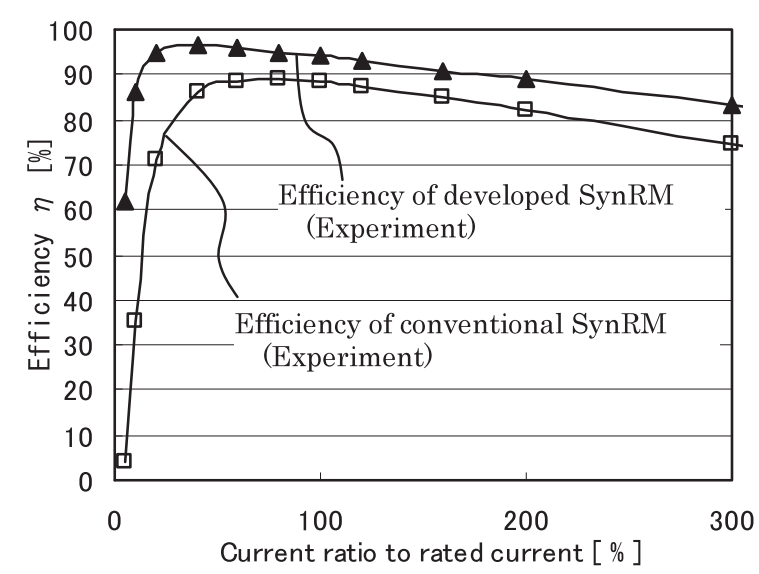

図 14 電流-効率 $\eta$ 特性

Fig. 14. Efficiency $\eta$ versus current.
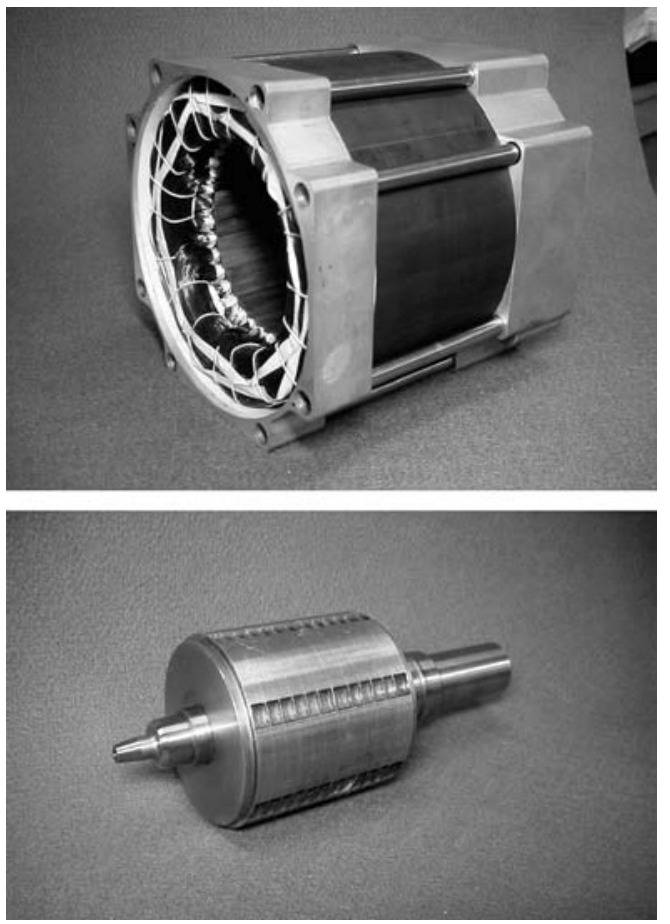

図 15 試作電動機の固定子と回転子の外観

Fig. 15. Prototype stator and rotor.

の $50 \%$ 以下の領域に抢いて従来電動機より試作電動機の方 が効率が顕著に改善している。これは, 図 7 のインダク夕 ンス特性に示すように，エアギャップの短縮等の $\mathrm{d}$ 軸方向 磁気抵抗の低減するための前記諸策の効果と, 回転子外周 の接続部を排除するなど q 軸インダクタンスの低減効果で ある。具体的には電流が低減され，銅損が低減している 効率 $\eta$ の評価は，次式により行った。

$$
\eta=(\omega T) /(\omega T+P c u+P f e)
$$

ここで, $\omega$ は回転各周波数 $2 \pi \times N / 60, T$ は出力トルクの実 測值， $P c u$ は銅損であり， $150^{\circ} \mathrm{C}$ に扔ける相抵抗值より計 算し，定格では $P c u=189 \mathrm{~W}$ である。Pfe は鉄損であり，
磁束密度 $1.5 \mathrm{~T}$, 周波数 $1000 \mathrm{~min}^{-1} / 60 \times 6$ pole $/ 2=50 \mathrm{~Hz}$ の条件で珪素鋼鈑 $35 \mathrm{~A} 270$, 压粉磁心の鉄損特性より計算 した。定格では $P f e=25 \mathrm{~W}$ である。低速回転であり，定 格に扔ける鉄損 $P f e$ は銅損 $P c u$ の 1/7 程度と小さい。

$\langle\mathbf{4} \cdot \mathbf{4}\rangle$ 製造上の効果と課題 試作電動機に採用した 生産性に関わる新技術および課題について以下に示す。

部分歯を採用する主目的は巻線の高占積率化, コイルエ ンドの短縮，巻線行程の生産性向上である。部分歯を装着 する前に巻線行程が行えることから, スロット開口部が広 い状態で巻線工程が行え，試作において前記の効果を得た。 巻線の挿入, 圧縮方法等，さらに改善の可能性がある。

圧粉磁心を採用して部分歯と称する歯の先端部部品を製 作し，使用した。ごく部分的な小さな部材であり，量産時 には，精密プレス成形での精度確保，材料コストを含めた 生産性確保は可能と考えている。量産用の金型と, 部分歯 を効率良く固定子へ装着するプレス装置が必要である。な お，圧粉磁心はいくつかの企業，研究機関で鉄損低減，高 磁束密度化等の研究が進められているが, 試作時点で入手 可能な圧粉磁心は，欠け易く，機械加工は難しいという問 題があった。

固定子と回転子間のエアギャップ長を $0.13 \mathrm{~mm}$ に短縮す ることは，精度的には最新の工作機械の高精度技術を活用 することにより実現可能である。ただ，設計的に各部品の 加工誤差，組み立て誤差，熱膨張誤差などを配慮した構造 設計が必要であると考える。

回転子構造に，接着剤付き珪素鋼板と補強用ステンレス 板による回転子の補強構造を採用した。製造工程的には回 転子の接着行程として, 加圧加熱が必要となる。実績が少 なく，確実な品質管理が必要である。また，接着剤以外の 溶接，かしめ等の補強方法との併用も可能である。

なお，SynRMの回転子のスリット形状はやや複雑であ るが，従来型 SynRM をプレス打ち抜き用順送金型で量産 しており, 生産実績がある。特に, 回転子内部のスリット 形状についてはプレス打ち抜きが可能な最小スリット幅と している。その結果, 電動機コアの生産性は, 誘導電動機 の電磁鋼板を量産用の順送金型で加工する場合と同等の生 産性が確認されている(2)(3)。

\section{5. あとがき}

スリット回転子を備えた SynRM は，高価な永久磁石を 使用しないので安価であり, 界磁弱め制御が可能であると いう特徴があるが，力率と電動機サイズの問題点があった。

本論文では，従来あまり行われていなかった固定子のコ ア構造, 巻線の巻回方法の改善および回転子構造の改善を 行い, 定格以内の大半の領域で力率 0.8 を実現し, 定格卜 ルクを従来比で $60 \%$ 増大した例を示し, SynRM の特性改 善の可能性を示した。特に, 電流の小さな領域から定格の 100\%の領域で力率，効率の改善が顕著であり，用途にもよ るが，従来型 SynRM，誘導電動機に比較して実用上の省工 交効果を期待できると思われる。 
今後は, 巻線の巻回方法の完成度の向上, 今回改良した 各電動機パラメータと特性向上との因果関係の把握などの 残っている技術課題を解決していきたいと考えている。

また, SynRMは，軟磁性体の磁気特性等の向上により電 動機性能がさらに向上する可能性があり, より広範囲な用 途での SynRM の活用が期待できると考えている。

(平成 16 年 9 月 28 日受付, 平成 17 年 8 月 10 日再受付)

\section{文献}

(1) M. Nashiki, A. Satake, Y. Kawai, T. Yokochi, and S. Okuma: "Analytical study of flux and experiments of a flux-barrier type reluctance motor with a slit rotor", T. IEE Japan, Vol.116-D, No.6, pp.694-701 (1996-6) (in Japanese)

梨木政行・佐竹明喜 ·川井庸市・横地孝典・大熊 繁：「スリット回 転子を用いたフラックスバリア型リラクタンスモータの磁界解析と 試作実験」, 電学論 D, 116, 6, pp.694-701 (1996-6)

(2) M. Nashiki, A. Satake, Y. Kawai, T. Yokochi, and S. Okuma: "Torque Ripple Reduction of Reluctance Motor with Slit Rotor", T. IEE Japan, Vol.117-D, No.8, pp.1008-1014 (1997-8) (in Japanese)

梨木政行・佐竹明喜 · 川井庸市・横地孝典・大熊 繁：「スリット回 転子を用いたリラクタンスモータのトルクリップル低減法」, 電学論 D, 117, 8, pp.1008-1014 (1997-8)

(3) M. Nashiki, A. Satake, Y. Kawai, T. Yokochi, and S. Okuma: "A New FluxBarrier-Type Reluctance Motor witha Slit Rotor", IEEE Trans. IES, Vol.46, No.6, pp.1199-1206 (1999-12)

(4) M. Nashiki, Y. Inoue, Y. Kawai, T. Yokochi, A. Satake, and S. Okuma: "Improvement of power factor and torque of a synchronous reluctance motor with a slit rotor", IEE Japan, RM-03-38, pp.25-30 ( ）(in Japanese) 梨木政行・井上芳光・川井庸市・横地孝典・佐竹明喜 · 大熊 繁 : 「スリット回転子を用いたリラクタンスモータの力率・トルク向上 に関する検討」, 回転機研資, RM-03-38, pp.25-30（）

(5) N. Matsui and Y. Takeda: "Reluctance Motors-State-of-the-art-", T. IEE Japan, Vol.118-D, No.6, pp.685-690 (1998-6) (in Japanese)

松井信行・武田洋次:「見直されてきたリラクタンスモータ」, 電学 論 D, 118, 6, pp.685-690 (1998-6)

(6) M. Morimoto, N. Matsui, and Y. Takeda: "Recent Advances of Reluctance Motors", T. IEE Japan, Vol.119-D, No.10, pp.1145-1148 (1999-10) (in Japanese)

森本雅之・松井信行・武田洋次：「リラクタンストルク応用電動機の 現状と動向」, 電学論 D, 119, 10, pp.1145-1148 (1999-10)

(7) K. Ohyama: "Recent Advances of Reluctance Torque Assisted Motors", IEE Trans. IA, Vol.123-D, No.2, pp.63-66 (2003-2) (in Japanese)

大山和伸 :「リラクタンストルク応用電動機の高性能化動向」, 電学 論 D, 123, 2, pp.63-66 (2003-2)

(8) Y. Honda, S. Kawano, H. Kiriyama, T. Higaki, S. Morimoto, and Y. Takeda: "Rotor Design and Perfomance of a Multi-Flux Barrier Synchronous Reluctance Motor", T. IEE Japan, Vol.118-D, No.10, pp.1177-1184 (1998-10) (in Japanese)

本田幸夫 · 川野慎一朗 · 桐山博之 ·檜垣俊郎 - 森本茂雄 ·武田洋次： 「マルチフラックスバリア型シンクロナスリラクタンスモータのロー 夕構造と特性比較」, 電学論 D, 118, 10, pp.1177-1184 (1998-10)

(9) H. Murakami, Y. Honda, S. Morimoto, and Y. Takeda: "Performance evaluation of Synchronous reluctance motor and the other motors with the same distributed winding and stator configuration", T. IEE Japan, Vol.114-D, No.6, pp.1068-1074 (2002-6) (in Japanese)

村上 浩・本田幸夫・森本茂雄・武田洋次：「シンクロナスリラク タンスモータと各種分布巻モー夕の特性比較」, 電学論 $\mathrm{D}, \mathbf{1 1 4}, 6$, pp.21068-1074 (1994-6)

(10) Y. Honda, H. Murakami, K. Narazaki, T. Higaki, S. Morimoto, and Y Takeda: "Optimum design of a multi layer interior permanent magnet synchronous motor using reluctance torque", T. IEE Japan, Vol.117-D, No.7, pp.898-904 (1997-7) (in Japanese)

本田幸夫 · 村上 浩 - 楢崎和成 - 檜垣俊郎 - 森本茂雄 · 武田洋次 : 「リラクタンストルクの有効利用をめざした多層埋込磁石構造 PM モー夕」, 電学論 D,117, 7, pp.898-904 (1997-7)

(11) H. Murakami, Y. Honda, S. Morimoto, and Y. Takeda: "Permanent Magnet Assisted Synchronous Reluctance Motor", T. IEE Japan, Vol.122-D, No.3, pp.266-272 (2002-3) (in Japanese)

村上 浩·本田幸夫・森本茂雄・武田洋次: 「永久磁石補助形シンク ロナスリラクタンスモータ」, 電学論 D, 122, 3, pp.266-272 (2002-3)

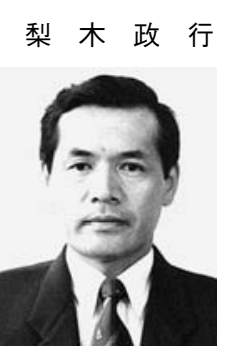

(正員) 1948 年 3 月 24 日生。 1970 年 3 月室蘭 工業大学電気工学科卒業。同年オークマ(株) 入 社。工作機械用サーボモー夕, その制御装置, 位 置検出器，メカトロニクスに関する開発に従事。 1979 年ブラシレスサーボモー夕開発。1993 年ス リット回転子を備えるシンクロナスリラクタンス モー夕開発。本研究終了後, 2003 年 4 月 (株) デ ンソーへ入社, 主幹。精密工学会会員。1 1986 年度 年精密工学会技術賞，1995 年度精密工学会賞，1999 年度精密工学会 技術賞を受賞。

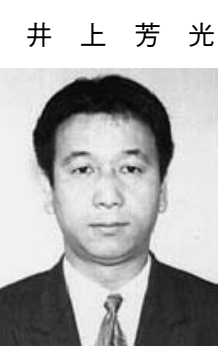

（非会員） 1969 年 9 月 21 日生。 1988 年 3 月岐 阜県立工業高等学校卒業。(株) 平松機械製作所 にて自動車部品生産設備設計。(株) 柏菱エンジ アリングにて航空機構造設計。2001 年オークマ （株）入社。シンクロナスリラクタンスモータ開 発，工作機械設計に従事。

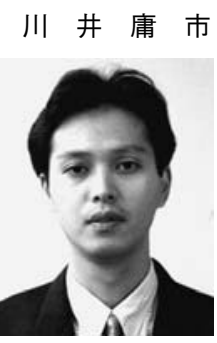

(非会員) 1963 年 12 月 6 日生。1987 年 3 月福井 大学工学部応用物理学科卒業。同年オークマ (株) 入社。 $\mathrm{CO} 2$ レーザ発振器の開発。現在, リラク夕 ンスモータ, リニアモータ, 及びメカトロニクス に関する開発に従事。

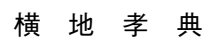

(非会員) 1967 年 9 月 1 日生。1992 年 3 月名古 屋大学工学部電子機械工学科卒業。同年オークマ (株) 入社。主としてアクチュエータ及び制御に 関する開発に従事。

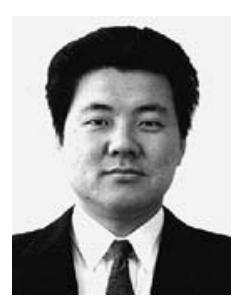

佐 竹 明 喜

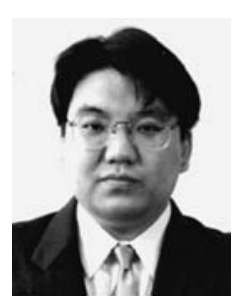

（正員） 1965 年 9 月 22 日生。 1990 年 3 月中部大 学大学院工学研究科博士前期課程電気工学専攻修 了。同年オークマ (株) 入社。主としてアクチュ エータ及び制御に関する開発に従事。計測自動制 御学会, 電子情報通信学会会員。

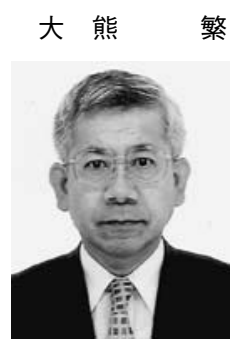

（正員） 1948 年 2 月 16 日生。1972 年 3 月名古 屋大学大学院工学研究科修士課程修了。1974 年 6 月ケース・ウェスタン・リザーブ大学大学院修士 課程システム工学専攻修了。1977 年 3 月名古屋 大学大学院博士課程修了。同年 4 月同大学助手, 1979 年 4 月同講師, 1984 年 11 月同助教授, 1990 年 12 月同教授, 現在に至る。工学博士。主とし て，ロボテイクス，パワーエレクトロニクス，創 発型ソフトコンピュータに関する研究に従事。IEEE IECON 論文賞, 精密工学会論文賞, 電気学会論文賞 2 回, ファナック FA ロボット財 団論文賞をそれぞれ受賞。IEEE, 計測自動制御学会, 日本ロボット学 会，システム制御情報学会，日本機械学会各会員。 